\title{
Caracterização de um vírus baciliforme isolado de Solanum violaefolium transmitido pelos ácaros Brevipalpus phoenicis e Brevipalpus obovatus (Acari: Tenuipalpidae)
}

\author{
Paulo de Tarso Oliveira Ferreira ${ }^{1}$, Eliane Cristina Locali-Fabris ${ }^{2}$, Juliana Freitas-Astúa ${ }^{2,3}$, Renata Antonioli-Luizon², \\ Renata Takasugui Gomes ${ }^{1}$, Marcos Antonio Machado ${ }^{2}$, Elliot Watanabe Kitajima ${ }^{1}$
}

${ }^{1}$ Dept. Entom., Fitopat. E Zool. Agrícola, Escola Superior de Agricultura “Luiz de Queiroz”, CP 9, 13418-900 Piracicaba, SP, Brasil; ${ }^{2}$ Centro APTA Citros Sylvio Moreira, CP 4, 13490-970 Cordeirópolis, SP; ${ }^{3}$ Embrapa Mandioca e Fruticultura Tropical, CP 7, 44380-000 Cruz das Almas, BA;

Autor para correspondência: E.W. Kitajima <ewkitaji@esalq.usp.br>

Data da chegada: 06/06/2005. Aceito para publicação em 20/11/2006.

\section{RESUMO}

Ferreira, P.T.O., Locali-Fabris, E.C., Freitas-Astúa, J., Antonioli-Luizon, R., Gomes, R.T., Machado, M.A., Kitajima, E.W. Caracterização de um vírus baciliforme isolado de Solanum violaefolium transmitido pelos ácaros Brevipalpus phoenicis e Brevipalpus obovatus (Acari:

Tenuipalpidae). Summa Phytopathologica, v.33, n.3, p.264-269, 2007

Solano-violeta (Solanum violaefolium) é uma planta ornamental rasteira usada para cobrir solos de áreas sombreadas. Um vírus que induz manchas anelares nas folhas desta planta, tentativamente designado Solanum violaefolium ringspot virus - SvRSV, transmitido pelo ácaro Brevipalpus phoenicis (Acari: Tenuipalpidae) foi encontrado em Piracicaba, SP. Trata-se de um vírus baciliforme que se assemelha a outros vírus do tipo citoplasmático transmitidos por Brevipalpus sp. Este trabalho teve como objetivo relatar propriedades biológicas e estabelecer uma caracterização molecular parcial do SvRSV. $\mathrm{O}$ vírus pode ser transmitido mecanicamente a várias outras espécies botânicas, causando lesões localizadas. Entre as espécies avaliadas, Datura stramonium mostrou-se a melhor hospedeira experimental. Observou-se também a manifestação de sintomas nestas plantas após infestação das mesmas por B. obovatus previamente alimentado em lesões de SvRSV, confirmando esta outra espécie de ácaro como vetor do vírus. Suas propriedades físicas in vitro foram: temperatura de inativação $40-45^{\circ} \mathrm{C}$; ponto final de diluição $10^{-3}-10^{-4}$; longevidade in vitro 12 dias. Em secções ultrafinas, as partículas do SvRSV mostraramse levemente mais delgadas e mais longas que as de outros vírus do mesmo grupo. A partir do dsRNA do SvRSV foi construída uma biblioteca de cDNA e foram identificadas duas possíveis regiões codificadoras das proteínas de movimento e replicase viral. Baseado nestas regiões foram desenhados "primers" para amplificação do RNA do SvRSV por RT-PCR. Sondas baseadas nas seqüências obtidas hibridizaram com ss- e dsRNA de D. stramonium infectadas pelo vírus. Ensaios preliminares de RT-PCR e hibridização não resultaram em reação com o vírus da leprose dos citros, tipo citoplasmático $(\mathrm{CiLV}-\mathrm{C})$.

Palavras-chave adicionais: SvRSV, CiLV-C, dsRNA, sequenciamento, efeito citopático

\begin{abstract}
Ferreira, P.T.O., Locali-Fabris, E.C., Freitas-Astúa, J., Antonioli-Luizon, R., Gomes, R.T., Machado, M.A., Kitajima, E.W. Characterization of a bacilliform virus isolated from Solanum violaefolium transmitted by the tenuipalpid mites Brevipalpus phoenicis and Brevipalpus obovatus. Summa Phytopathologica, v.33, n.3, p.264-269, 2007

Solanum violaefolium is an ornamental plant, with prostrate, trailing growth habit and is cultivated in shaded areas. A virus that causes ringspot symptoms on its leaves, tentatively named as Solanum violaefolium ringspot virus (SvRSV) and transmitted by Brevipalpus phoenicis (Acari: Tenuipalpidae) was found in Piracicaba city, São Paulo State. It is a bacilliform virus that resembles other cytoplasmic viruses transmitted by Brevipalpus sp. The objective of this work is to describe the biological properties and establish partial molecular characterization of the SvRSV. The SvRSV can be transmitted mechanically to several plant species causing local lesions. Among the tested species, Datura stramonium was proved to be the best experimental host. It was observed that $S$. violaefolium plants were infested by $B$. obovatus that also transmitted SvRSV in preliminary

assays. Its in vitro physical properties were: thermal inactivation point: $40-45^{\circ} \mathrm{C}$; dilution end point: $10^{-3}-10^{-4}$ and in vitro longevity: 12 days. Ultrathin sections revealed that SvRSV particles are slightly thinner and longer than other cytoplasmic-type viruses transmitted by Brevipalpus sp. A cDNA library from dsRNA molecules extracted from SvRSV was constructed and two regions, which putatively code for the replicase and movement proteins were identified. Based on these sequences, primer pairs were designed for SvRSV's RNA amplification by RT-PCR. Indeed, probes based on such sequences hybridized with ss- and dsRNA from infected $D$. stramonium plants. Preliminary molecular assays using primers and probes of SvRSV did not detect Citrus leprosis virus, cytoplasmic type (CiLV-C), another cytoplasmic type Brevipalpus-transmitted viruses.
\end{abstract}

Additional Keywords: SvRSV, electron microscopy, dsRNA, sequencing, cytopatic effect, CiLV-C 
Solanum violaefolium Schott (Bitter), Solanaceae, conhecida como solano-violeta, é uma planta ornamental de crescimento rasteiro (14). Apesar de ser de importância econômica secundária, ela tem sido alvo de estudos, por se infetar com um vírus baciliforme transmitido por Brevipalpus phoenicis Geijskes (Acari: Tenuipalpidae) à semelhança da leprose dos citros, doença causada pelo vírus da leprose dos Citros (Citrus leprosis virus cytoplasmic type- CiLV-C) (18), mancha anular

do cafeeiro, causada pelo Coffee ringspot virus - CoRSV (2), pinta verde do maracujazeiro, causada pelo Passion fruit green ringspot virus - PFGSV (10), mancha anular das orquídeas, causada pelo Orchid fleck virus -OFV (17) entre outras (9). O ácaro vetor é uma espécie polífaga e apresenta distribuição cosmopolita (7), sendo sua presença no Brasil confirmada em 1959 (19). Dentre estes vírus, a leprose dos citros, originalmente descrita nos EUA (4), destaca-se como um dos principais problemas da citricultura paulista, ocorrendo também em vários outros Estados da União (19). Seus prejuízos diretos têm sido avaliados entre 40 a 60 milhões de dólares/ano (22) e o custo do controle do ácaro vetor em cerca de 80 milhões de dólares (19).

Há dois padrões citopáticos induzidos pelos vírus transmitidos por Brevipalpus. O padrão nuclear: com partículas em forma de bastonete curto, geralmente associadas à membrana do envólucro nuclear ou do retículo endoplasmático, e com viroplasma elétron transparente no núcleo e o padrão citoplasmático: com partículas baciliformes dotadas de membrana, contidas no lúmem do retículo endoplasmático e viroplasma elétron denso no citoplasma (9). Eventualmente, os dois tipos podem ocorrer numa mesma célula, em caso de infecção mista como observado por Kitajima et al. (9).

Além das características morfológicas, são desejáveis dados sobre as propriedades físico-químicas, antigênicas e moleculares para a correta classificação destes vírus. As relações entre os vários vírus transmitidos por Brevipalpus ainda não estão esclarecidas e é possível que algumas dessas relações tenham papel importante na cadeia epidemiológica das doenças de interesse econômico. Devido a sua labilidade, não foi possível purificar o SvRSV apesar de inúmeras tentativas.

Só recentemente houve alguns avanços sobre o genoma destes virus. Kondo et al. (11) obtiveram a seqüência completa do Orchid fleck virus - OFV, do tipo nuclear. Após a obtenção de fragmentos do genoma do CiLV-C foi possível estabelecer métodos moleculares para a detecção (13) e completar a seqüência do genoma do CiLV-C (R. Pascon et al., 2005, comunicação pessoal).

O objetivo deste trabalho foi caracterizar biológica e molecularmente o SVRSV e procurar estabelecer uma correlação entre este e o CiLV, que têm bastante semelhanças na morfologia das partículas e efeitos citopáticos

\section{MATERIAL E MÉTODOS}

\section{Vírus}

Isolados do SvRSV foram originalmente encontrados em Piracicaba, SP nos jardins do Hotel Beira Rio e Clube de Campo e mantidos em condições de casa-de-vegetação.

\section{Ensaios de transmissão}

Transmissão mecânica - Folhas de plantas de S. violaefolium infectadas com SvRSV foram trituradas juntamente com tampão fosfato $\left(0,01 \mathrm{M}, \mathrm{pH} 7,2+0,1 \%\right.$ de $\left.\mathrm{NaSO}_{3}\right)$ até obtenção de um extrato. Foram inoculadas 38 espécies de plantas de 14 famílias botânicas com o macerado contendo o vírus. Em seguida, foram mantidas em condições de casa-de-vegetação até a manifestação dos sintomas.

Transmissão pelo ácaro Brevipalpus - Ácaros B. phoenicis avirulíferos, criados em frutos de laranja, foram transferidos para plantas de $S$. violaefolium infectadas pelo SvRSV por um período de 5 dias e após aquisição do vírus através da alimentação, estes foram transferidos para plantas-teste sadias nas quais permaneceram por um período de três dias. Os ácaros foram eliminados com acaricida (p. a. Dicofol) e as plantas foram mantidas em casa de vegetação até a manifestação dos sintomas. A presença de vírus nas lesões foi averiguada por técnicas de microscopia eletrônica e inoculação mecânica em hospedeira suscetível.

Em outro ensaio, após a constatação da ocorrência de B. obovatus Donadieu em plantas de S.violaefolium infectada com o SvRSV, procurou-se verificar se este ácaro transmite o vírus. As etapas de aquisição e inoculação foi a mesma citada anteriormente. Vinte ácaros vírulíferos foram colocados em cinco plantas de Datura stramonium L. Foram feitas três repetições.

\section{Determinação de propriedades físicas in vitro}

Ponto final de diluição do vírus: Dois gramas de tecido com lesão de SvRSV em D. stramonium, que é uma hospedeira suscetível, foram macerados em $10 \mathrm{~mL}$ de tampão fosfato de sódio $(0,01 \mathrm{M})$. Diluições de $10^{-1}$ a $10^{-7}$ foram feitas e inoculadas em quatro plantas de D. stramonium sadias. Foram feitas três repetições para cada diluição. A observação do aparecimento de sintomas foi feita diariamente durante 15 dias.

Temperatura de inativação do vírus: Para determinação da temperatura de inativação, o inóculo do vírus foi submetido por 10 min a diferentes temperaturas $\left(30{ }^{\circ} \mathrm{C}\right.$ a $\left.70{ }^{\circ} \mathrm{C}\right)$. Ao atingir cada temperatura de interesse, plantas de Datura foram inoculadas e mantidas em observação durante 15 dias. Foram utilizadas quatro plantas da hospedeira em cada uma das três repetições.

Conservação do vírus: Para este ensaio foram utilizadas quatro plantas de $D$. stramonium em duas repetições. O inóculo do vírus foi conservado à temperatura ambiente em frascos e inoculados na plantateste diariamente até o $25^{\circ}$ dia. As leituras dos sintomas foram feitas em intervalos diários após a inoculação.

A metodologia da deteminação das propriedades físicas foi feita baseda em Ross (20) com adaptações.

\section{Microscopia eletrônica de transmissão (MET)}

Para avaliar os efeitos citopáticos, os tecidos de plantas infetadas foram preparados de acordo com Kitajima (8). Amostras de tecidos foram pré-fixadas em solução de Karnovsky modificado, fixadas em ácido ósmico $\left(\mathrm{Os}_{4}\right)$ e desidratadas com uma diluição seriada de acetona $(30,50,70,90$ e 100\%), por 10 min cada. As amostras foram infiltradas com uma mistura de acetona e resina "spurr" $(1: 1)$ por $3 \mathrm{~h}$ e finalmente com resina "spurr" pura durante $16 \mathrm{~h}$. As amostras foram colocadas durante $48 \mathrm{~h}$ a $70^{\circ} \mathrm{C}$ em formas de silicone. Secções ultrafinas feitas no ultramicrótomo foram contrastadas com acetato de uranila a $3 \%$ e citrato de chumbo. A visualização das secções foi feita ao microscópio eletrônico de transmissão (Zeiss EM 900).

\section{Microscopia de luz}

Aspectos anatômicos das lesões em tecidos foliares foram analisados segundo metodologia utilizada por Glória et al. (6). Tecidos de $S$. violaefolium com lesões de SvRSV foram fixados em solução de Karnovsky. As amostras foram desidratadas numa série de etanol (30, $50,70,90$ e $100 \%$ ) e infiltradas com a resina glicol metacrilato da Reichert-Jung. Foram feitas secções de 5 ìm de espessura em micrótomo rotativo manual. As secções foram coradas com azul de toluidina e montadas em resina sintética "Entellan" (Merck). As imagens foram 
observadas em um microscópio de luz (Zeiss) e capturadas por meio de uma câmera digital ligada ao computador.

\section{Caracterização Molecular do SvRSV}

Isolamento de dsRNA - Isolamento do dsRNA do SvRSV foi obtido a partir de 2 gramas de lesão em folhas de D. stramonium inoculadas com SvRSV segundo metodologia utilizada para isolamento do dsRNA do CiLV-C de acordo com Locali (12). Após a extração do dsRNA, este foi purificado através da utilização de duas enzimas Mung Bean Nuclease (Gibco BRL, Gaithersburg, MD) e DNAse I RNAse-free (Boehringer Mannheim, Germany), de acordo com as recomendações dos fabricantes, para eliminação de contaminantes como ssRNA ou DNA da planta e através da purificação das bandas em gel de agarose LMP $1 \%$.

Construção da biblioteca de cDNA e sequenciamento - Cerca de $150 \mathrm{ng}$ do dsRNA purificado foi denaturado a $95^{\circ} \mathrm{C}$, por $5 \mathrm{~min}$ seguido de síntese da primeira fita de cDNA usando a enzima MMLV-RT Transcriptase Reversa (Invitrogen) e um iniciador oligodT, segundo instruções do fabricante.

A síntese da segunda fita de cDNA foi realizada, utilizando a enzima DNA Polimerase I (Promega Co., Madison, WI) de acordo com as recomendações do fabricante seguida de uma extração com fenol:clorofórmio e precipitação com etanol absoluto e acetato de sódio 3M.

Em seguida o cDNA foi ligado a adaptadores e amplificado por Nested PCR com pequenas modificações do protocolo da "Bacterial Genome Subtraction Kit - Clontech PCR - select kit (Clontech, Palo Alto, CA), conforme descrito em Locali (12).

$\mathrm{O}$ produto dessa reação foi diluído 10 vezes e $5 \mu \mathrm{L}$ foram usados para a segunda reação, como descrito anteriormente. O produto da PCR foi avaliado em gel de agarose $1 \%$ e em seguida os fragmentos amplificados foram purificados em gel de agarose LMP 0,8\% e kit QIAquick - gel Extraction (QIAGEN).

Para clonagem, $10 \mu \mathrm{L}$ do produto da PCR purificado, foram utilizados na reação de ligação, adicionando $1,0 \mu \mathrm{L}$ do vetor $\mathrm{pGEM}-\mathrm{T}$ (Promega.), O procedimento de transformação foi feito segundo Sambrook et al. (23). As reações de seqüenciamento foram realizadas de acordo com as instruções da Perkin Elmer para o "DNA Sequencing Kit Big Dye Terminator cycle sequencing ready reaction", v 3.0 e o seqüenciamento foi feito no aparelho ABI 3700 - Perkin Elmer (Applied Biosystems, Foster City, CA).

Análise das seqüências e desenho de primers - As seqüências obtidas foram analisadas utilizando o programa Sequencing Analysis da Perkin Elmer, Seq Man - LASERGENE 99 (DNASTAR Inc., Madison, WI) e a qualidade das mesmas foi verificada através do programa "Phred-Phap-Consed", usando critério de classificação de pelo menos 300 bases por seqüência com qualidade acima de 20 . As seqüências foram alinhadas utilizando o programa "CAP 3". Seqüências de adaptadores e vetores empregados na clonagem foram removidas antes das análises. As seqüências de DNA correspondentes aos "contigs" obtidos após análise, foram comparados com aquelas disponíves na base de dados GenBank usando BLASTx e BLASTn (1) acessados pelo NCBI (National Center for Biotechnology Information).

Seqüências com similaridade a regiões genômicas de vírus que codificam proteínas putativas foram usadas para desenhar primers por meio do programa "Primer 3" (21). De acordo com as regiões genômicas identificadas, os primers desenhados para a região genômica que codifica para replicase viral foram: $\boldsymbol{F} \mathbf{1}-5$ '-tgtcgaactttggtatgagtcg3'; R2 - 5'-ccggttcgtcaaataactcc-3'; F3 -5' -atgaccgaacatcacgatcc-3';
$\boldsymbol{R} 4$ - 5' -gaacgtccctccgtcacc-3'; F5 - 5' -tggtatgagtcgcatgttga-3' e $\boldsymbol{R} \boldsymbol{6}$ 5 '-tgtcctgaacagggatcaaa-3'. Aqueles desenhados para a região genômica que codifica para proteína de movimento viral foram: $\boldsymbol{F} 7$ - 5'caacatccaccaaaatcgac-3' e $\boldsymbol{R} \boldsymbol{8}$ - 5'-gtgcgaattggaatctttgc-3'.

RT-PCR para detecção de SvRSV - A extração de RNA total de plantas de $S$. violaefolium e Citros foi feita utilizando cerca de $100 \mathrm{mg}$ de folhas sintomáticas para SvRSV e CiLV-C respectivamente. Os tecidos foram macerados e o RNA total foi extraído de acordo com protocolo de Gibbs \& Mackenzie (5). Também foi utilizado o controle sadio para cada amostra. Este RT-PCR foi feito para validação dos primers. O cDNA das amostras foi feito usando $2,5 \mu \mathrm{L}$ de RNA total, $1 \mu \mathrm{L}$ de dNTP, $0,5 \mu \mathrm{L}$ de primers randômicos e $8,5 \mu \mathrm{L}$ de água MilliQ. A reação foi incubada a $95^{\circ} \mathrm{C}$ por 5 min e colocada no gelo. Foram adicionados a esta reação $5 \mu \mathrm{L}$ de tampão $5 \mathrm{X}$ PCR (Invitrogen), $2 \mu \mathrm{L}$ de DTT, 0,5 $\mu \mathrm{L}$ de RNAse-out e $1 \mu \mathrm{L}$ da enzima M-MLV-RT (Invitrogen). A reação foi encubada a $37^{\circ} \mathrm{C}$ por $70 \mathrm{~min}$. Para o PCR 2,5 iL de cDNA foram adicionados a $1 \mathrm{X}$ de tampão PCR 10X (Invitrogen), 1,8 mM de $\mathrm{MgCl}_{2}$ (50mM), 1,25 mM de dNTP 2,5 mM, 100ng/ $\mu \mathrm{L}$ de cada primer $(200 \mathrm{ng} / \mu \mathrm{L}), 1 \mathrm{U}$ da enzima Taq-DNA Polimerase (5U/ $\mu \mathrm{L}$ ) e água Milli-Q estéril para um volume final de $25 \mu \mathrm{L}$. O programa de temociclagem constou de 1 ciclo de $94{ }^{\circ} \mathrm{C}$ por 2 minutos, 33 repetições de $94{ }^{\circ} \mathrm{C}$ por 30 segundos, $52{ }^{\circ} \mathrm{C}$ por 40 segundos e $72{ }^{\circ} \mathrm{C}$ por 40 segundos, 1 ciclo de $72{ }^{\circ} \mathrm{C}$ por 10 minutos. Os resultados das amplificações foram avaliados por meio de eletroforese em gel de agarose $1 \%$.

Hibridizações. Cada um dos clones 01E04, 01A09 e 01E12, correspondentes à região genômica que codifica a replicase viral e os clones 03G02, 03A04 e 02F07, identificados como parte da região genômica que codifica a proteína de movimento do SvRSV, foram marcados por quimioluminescência de acordo com especificações do manual do kit utilizado para marcação das sondas (DIG DNA Labeling Kit - Roche Molecular Biochemicals). Cada clone foi utilizado como sonda em uma membrana. Dois $\mu \mathrm{L}$ do DNA do clone foram colocados em membrana de Nylon (Hybond N - Amersham), além de amostras de dsRNA e ssRNA do SvRSV obtidos de plantas de Datura sintomáticas e sadias, além de, amostras de ssRNA total de plantas de laranjeira sintomáticas para leprose. As reações de hibridização foram realizadas de acordo com Sambrook et al. (23).

\section{RESULTADOS E DISCUSSÃO}

Ensaios de transmissão. Os sintomas apresentados de maneira geral caracterizaram-se por manchas cloróticas, em alguns casos podendo evoluir para necrose. Em folhas senescentes, observou-se mancha verde. Entre as 38 plantas utilizadas nos ensaios de transmissão por inoculação mecânica, Capsicum annuum L., Chenopodium amaranticolor Coste \& Reyn, C. quinoa Willd., D. stramonium, D. suaveolens (Willd.) Bercht. \& J. Presl, Gomphrena globosa L., Hibiscus cannabinus L., Lycopersicum esculentum Mill., Nicotiana benthamiana Domin., N. clevelandii Gray., N. glutinosa L., N. rustica L., N. tabacum L. e $S$. violaefolium mostraram sintomas de mancha verde/clorótica. Quando colonizadas com ácaros B. phoenicis virulíferos, C. annuum, D. stramonium, D. suaveolens, $H$. cannabinus, $N$. clevelandii, $N$. tabacum, Salvia leucantha Cav., Thunbergia erecta (Benth.) T. And. e $S$. violaefolium apresentaram sintomas semelhantes aos da inoculação mecânica. Nos ensaios de transmissão do SvRSV por B. obovatus foi verificado que também ocorre a transmissão do vírus para plantas de D. stramonium. Das 15 plantas inoculadas, todas mostraram sintomas.

Em plantas de C. quinoa, C. amaranticolor e G. globosa, nenhum ácaro foi encontrado durante o período de alimentação para inoculação, 
o que sugere que essas plantas não são boas hospedeiras para o vetor. Lovisolo et al. (16) também não obtiveram sucesso em transmitir o CiLV com ácaros virulíferos para estas hospedeiras.

Microscopia eletrônica de transmissão. Análises das secções ultrafinas de tecidos lesionados mostraram efeito citopático do tipo citoplasmático, com grupos de partículas baciliformes no lúmen do retículo endoplasmático e viroplasma elétron denso no citoplasma (Figura 1)

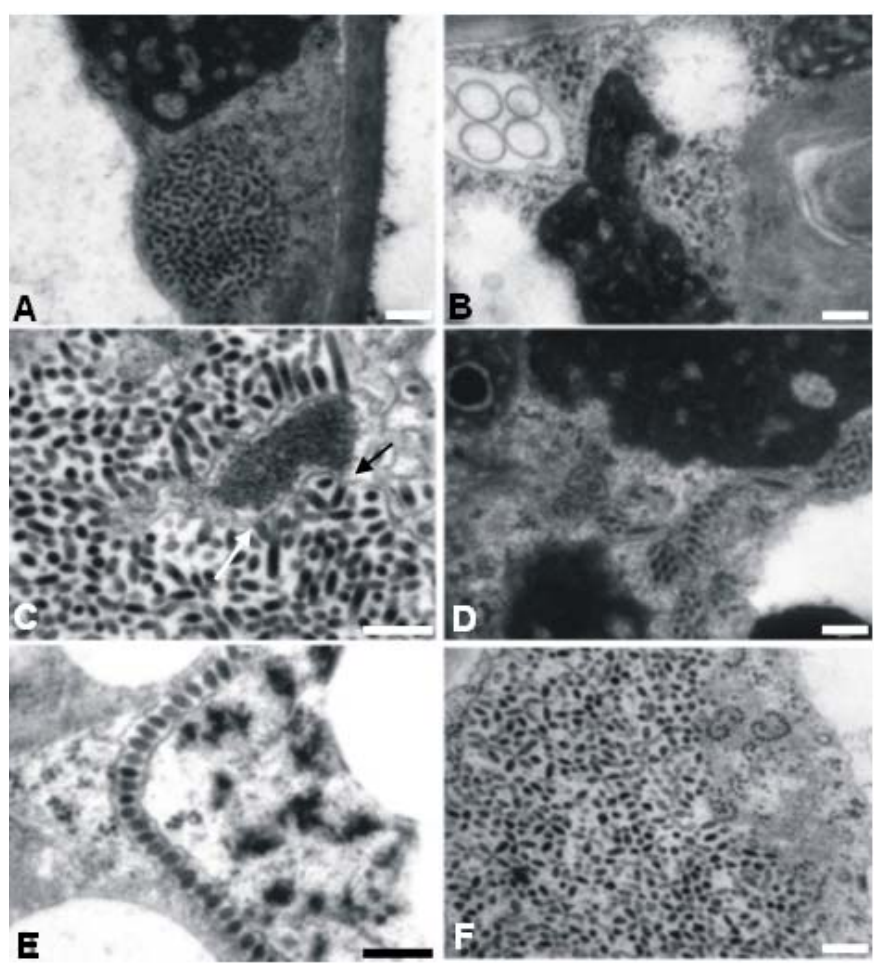

Figura 1. Micrografia de seções ultrafinas de tecidos com lesões com sintomas do SvRVS. (A) Datura suaveolens; (B) Salvia leucantha; (C) Thumbergia erecta; (D) Solanum violaefolium; (E) Hibiscus cannabinus; (F) Capsicum annum. A seta indica "brotação" das partículas. A barra representa $200 \mathrm{~nm}$

Em secções das lesões, tanto em $S$. violaefolium, como nas das hospedeiras para as quais o vírus foi transmitido, observaram-se efeitos citopáticos essencialmente similares (Figura 1A-F). Numerosas partículas baciliformes de cerca de 50-60 nm em diâmetro, avaliados em secções transversais, e de comprimento variável (100 nm - $1 \mu \mathrm{m})$, foram notadas sempre no lúmen de cavidades limitadas por membrana única, derivadas do retículo endoplasmático. As partículas possuem uma membrana envoltória.

O SvRSV difere de outros vírus do tipo citoplasmático transmitidos pelo Brevipalpus, pela heterogeneidade do comprimento das partículas, visto que dos outros vírus o comprimento é em torno de $110-120$ $\mathrm{nm}$. As membranas das partículas virais podem apresentar continuidade com a membrana da cavidade (Figura 1C), evidenciando que o material que compõe o viroplasma seria precursor dos vírions.

A diferença na morfologia das partículas do SvRSV em secções quando comparado com outros vírus do tipo citoplasmático transmitido por ácaros Brevipalpus sugere que talvez ele represente um sub-tipo deste grupo.

Microscopia de luz. Em análises morfo-anatômicas de folhas de S. violaefolium, observaram-se alterações nos tecidos infectados quando comparados com tecidos de folhas sadias, caracterizadas por hipertrofia de algumas células da epiderme e do parênquima lacunoso (Figura 2).

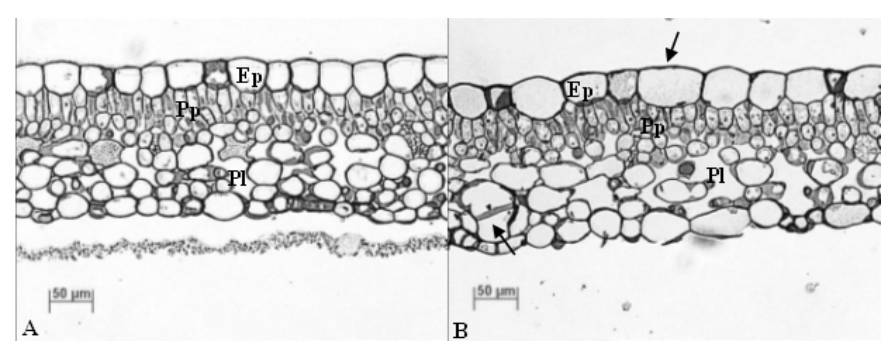

Figura 2. Secções transversais da lâmina foliar de Solanum violaefolium. A - Tecido sadio. B - Tecido infectado com SvRVS. Em B, a ponta da seta mostra células hipertrofiadas na epiderme e no parênquima lacunoso. $\mathrm{Pp}-$ Parênquima paliçádico, Pl - Parênquima lacunoso, Ep - Epiderme.

\section{Determinação de propriedades físicas in vitro}

Ponto final de diluição do vírus: Após as inoculações, foi observado que apenas as frações diluídas até $10^{-3}$ foram capazes de induzir lesões em $D$. stramonium. Sendo assim, pode-se considerar que o ponto final de diluição do SvRSV está entre $10^{-3}$ e $10^{-4}$. Lovisolo et al. (15), trabalhando com a leprose dos citros, mostraram que inoculando o CiLV em plantas de C. quinoa, o ponto final de diluição foi de $10^{-3}$. Enquanto Chagas (3), obteve um ponto final de $10^{-4}$ para a mancha anelar do café inoculada também em C. quinoa.

Ponto de inativação térmica do vírus: Apenas as inoculações efetuadas com suco previamente submetido às temperaturas de até $40^{\circ} \mathrm{C}$ conseguiram induzir sintomas em $D$. stramonium. Para a leprose dos citros, o ponto de inativação térmica ficou entre $55-60{ }^{\circ} \mathrm{C}$ (15). Já a mancha anelar do café apresentou uma inativação térmica em torno de $70{ }^{\circ} \mathrm{C}(3)$.

Conservação do vírus: $O$ extrato da planta conservado a temperatura ambiente se manteve infectivo por 12 dias. Usando tampão fosfato $(\mathrm{pH} 7,0)$ contendo Na-DIECA, EDTA e tioglicolato, Lovisolo et al. (15) conseguiram transmitir o CiLV após seis dias da extração da folha sintomática, conservando-o a $4{ }^{\circ} \mathrm{C}$. Já à temperatura ambiente, a infectividade se manteve por apenas três dias (16). Chagas (3) mostrou que a infectividade do CoRSV se mantém por 19 dias à $4{ }^{\circ} \mathrm{C}$.

\section{Caracterização Molecular}

Isolamento de dsRNA - O padrão de bandas obtido a partir da extração do dsRNA do SvRSV foi uma banda intensa de aproximadamente $10 \mathrm{~Kb}$ e outra de $3 \mathrm{~Kb}$, tanto em D. stramonium quanto em $S$. violaefolium (dados não mostrados). Em plantas sadias não foi observado a presença de dsRNA.

\section{Comparação com outros vírus no Genbank}

A partir da biblioteca de cDNA, obtiveram-se 6 clones, cujas seqüências formaram 4 "contigs", de 252, 325, 600 e 535 pb. Os três primeiros codificam parte da provável proteína da replicase (rep) e o último uma provável proteína de movimento $(m p)$ quando comparado com as seqüências depositadas no GenBank. A seqüência foi depositada no GenBank com número de acesso DQ 514336.

As seqüências parciais da rep e $m p$ apresentam similaridade com aquelas de membro dos gêneros Furovirus, Tobamovirus e da família Bromoviridae como ocorreu com CiLV-C, embora não se tenha 
constatado similaridade nas seqüências com o do CiLV-C. Vale ressaltar que, apesar de ter seu genoma seqüenciado, poucas seqüências do CiLV-C estão disponíveis em bancos de seqüências públicos. Não houve similaridade com seqüências de vírus da família Rhabdoviridae. Isto já foi constatado com fragmentos do genoma do CiLV-C (13) e confirmado quando a seqüencia completa do genoma do virus foi obtida (Pascon et al., Locali et al., comunicação pessoal). Esses resultados aliados ao fato de o CiLV-C ter genoma de ssRNA, de sentido positivo e bipartido reforçam a hipótese de que este vírus não é um membro da família Rhabdoviridae.

\section{Síntese de iniciadores (primers) e PCR para deteç̧ão}

A amplificação de amostras de D. stramonium e $S$. violaefolium infectadas com SvRSV resultou em fragmentos de diversos tamanhos, sendo o maior deles de 600 pb (dados não mostrados). O par de primers F1 e R2 se mostrou o mais específico entre as quatro combinações testadas, sendo que, após sua otimização, as amplificações de material infectado com SvRSV mostraram-se bastante específicas (Figura 3). Utilizando-se esses primers, foi possível detectar a presença do vírus através da amplificação de banda única apenas em amostras de $S$. violaefolium e $D$. stramonium infectadas com SvRSV e não nas amostras sadias. Os demais pares de primers reagiram inespecificamente com as amostras sadias testadas.

\section{Hibridizações}

Cada clone teve um comportamento distinto em "dot blot" como pode ser observado na Tabela 1. A sonda obtida a partir do clone 01A09 não hibridizou com qualquer uma das amostras

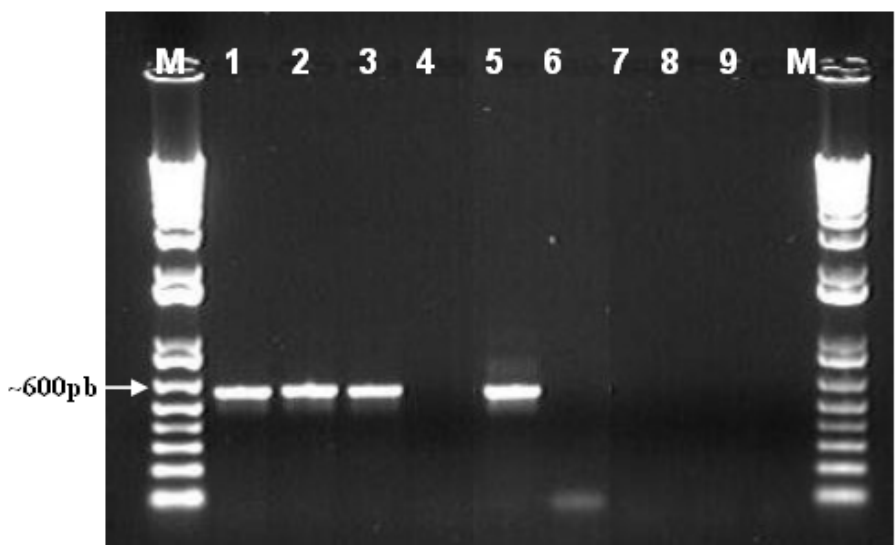

Figura 3. Gel de agarose $1 \%$ do produto de PCR dos primers F1 e R2. M - marcador Ladder $1 \mathrm{~Kb}$ plus; 1 a 3 - RNA total de solano infectada com SvRSV; 4 - RNA total de solano sadia; 5 - dsRNA de solano com SvRSV; 6 - dsRNA de solano sadia; 7 e 8 - RNA de citros com CiLV-C; 9 - RNA de citros sadio espotadas na membrana, nem ao menos com o próprio DNA controle, o que indica que a marcação desta sonda não foi eficiente.

A sonda obtida a partir do clone 01E12 hibridizou apenas com o DNA do controle positivo, o que sugere que este clone não representa parte genômica do vírus nem mesmo da planta hospedeira e sim um contaminante. As sondas 01E04, 02F07, 03A04 e 03G02, representam os clones que hibridizaram com o RNA total extraído de plantas de D. stramonium sintomáticas para o SvRSV bem como o dsRNA de D. stramonium sintomática para o SvRSV indicando que tais clones apresentam similaridade com o material genômico do vírus, pois hibridizaram somente com amostras de plantas infectadas. Ausência de reação com o dsRNA dos clones 01E04 e 02F07 provavelmente ocorreu em função da baixa concentração desses dsRNA nas amostras. Em nenhuma das membranas foi observada reação de hibridização com o controle negativo (planta sadia), indicando que os clones obtidos não são provenientes do genoma da planta. Nenhuma das sondas obtidas a partir de clones do SvRSV hibridizaram com RNA total de plantas de citros sintomáticas para o CiLV$\mathrm{C}$, indicando aparentemente não haver homologia entre estes segmentos genomicos identificados do SvRSV com o CiLV-C.

Em conclusão, o conjunto de informações disponíveis indica que o SvRSV é transmitido pelos ácaros $B$. phoenicis e $B$. obovatus, bem como mecanicamente para $S$. violaefolium e diversas outras hospedeiras, sempre resultando em infecção localizada. A morfologia de suas partículas e as alterações citopáticas induzidas nas células infectadas são características dos vírus transmitidos por ácaros Brevipalpus, do tipo citoplasmático. Sua morfogênese parece ser por "brotação" a partir de material do viroplasma. Após obtenção de fragmentos do genoma deste vírus, observou-se pela análise de suas seqüências que têm homologia com proteínas de movimento e de replicase de alguns vírus de planta, similares às observadas com o CiLV-C. Contudo, não houve identidade entre as seqüências de SvRSV e CiLV-C. Os primers desenhados e as sondas não reconheceram até agora o $\mathrm{CiLV}-\mathrm{C}$, confirmando a baixa identidade entre as seqüências conhecidas deste e o SvRSV. O CiLV-C, que tem o seu genoma completamente seqüenciado, seria definitivamente distinto dos rhabdovirus devendo representar um novo grupo de vírus. SvRSV pelas características gerais pertenceria a este grupo, mas os dados existentes sugerem que seriam vírus distintos. Esta distinção se deve também em função do tamanho das partículas do SvRSV. Vale mencionar que apesar de várias tentativas SvRSV não infectou plantas cítricas, mas CiLV-C (J.C.V. Rodrigues, comunicação pessoal) causou lesões cloróticas em $S$. violaefolium em ensaios de transmissão por ácaros, e o efeito citopático observado foi o mesmo observado em lesões lepróticas de citros.

Tabela 1. Resultado da hibridização por "dot blot" das amostras de dsRNA, ssRNA de Datura stramonium, ssRNA de Citros com leprose e os clones com homologia a putativa proteína de movimento e replicase

\begin{tabular}{|c|c|c|c|c|c|c|}
\hline \multicolumn{3}{|c|}{ dsRNA } & \multicolumn{3}{|c|}{$\operatorname{ssRNA}$} & \multirow{2}{*}{$\begin{array}{l}\text { DNA } \\
\text { Controle }\end{array}$} \\
\hline Sonda & Datura SvRSV & Datura sadia & Datura SvRSV & Datura sadia & Citros CiLV-C & \\
\hline $01 \mathrm{~A} 09$ & - & - & - & - & - & - \\
\hline $01 \mathrm{E} 04$ & - & - & + & - & - & + \\
\hline $01 \mathrm{E} 12$ & - & - & - & - & - & + \\
\hline $02 \mathrm{~F} 07$ & - & - & + & - & - & + \\
\hline $03 \mathrm{~A} 04$ & + & - & + & - & - & + \\
\hline 03G02 & + & - & + & - & - & + \\
\hline
\end{tabular}




\section{REFERÊNCIAS BIBLIOGRÁFICAS}

1. Altschul, S.F.; Madden, T.L.; Schaffer, A.A.; Zhang, J.; Zhang, Z.; Miller, W.; Barret, A.J. Gapped BLAST and PSI-BLAST: A new generation of protein database search programs. Nucleic Acid Research, Cambridge, v.25, p.3389-3402, 1997.

2. Chagas, C. M. A associação do ácaro Brevipalpus phoenicis (Geijskes) à mancha anular do cafeeiro. O Biológico, São Paulo, v.39, p.229-232, 1973.

3. Chagas, C.M. Mancha anular do cafeeiro: transmissibilidade, identificação do vetor e aspectos anátomo-patológicos da espécie Coffea arabica L. afetada pela moléstia. 1978. 132p. Tese (Doutorado) - Instituto de Biociências, Universidade de São Paulo, São Paulo.

4. Fawcett, H. S. Citrus diseases and their control. New York: McGraw Hill, 1936. 582p.

5. Gibbs, A.; Mackenzie, A. A primer pair for amplifying part of the genome of all potyvirids by RT-PCR. Journal of Virological Methods, London, v.63, p.9-16, 1997.

6. Glória, B.A.; Capote-Albernaz, M.C.; Amorim, L. Structural characteristics of buds of sugarcane cultivars with different levels for resistance to smut. Journal of Plant Diseases and Protection, Stuttgart, v.102, p.502-508, 1995.

7. Haramoto, F. H. Biology and control of Brevipalpus phoenicis (Geijskes, 1939)(Acarina: Tenuipalpidae). Hawaii Agricultural Experimental Station Technical Bulletin, Honolulu, n.68, p.1$60,1969$.

8. Kitajima, E. W. Curso introdutório de microscopia eletrônica de transmissão, Piracicaba: ESALQ, 1998. 43 p.

9. Kitajima, E. W.; Chagas, C. M.; Rodrigues, J. C. V. Brevipalpustransmitted plant virus and virus-like diseases: cytopathology and some recent cases. Experimental and Applied Acarology, Amsterdam, v.30, p.135-160, 2003.

10. Kitajima, E. W.; Rezende, J. A. M.; Rodrigues, J. C. V.; Chiavegato, L. G.; Piza Junior, C. T.; Morozini, W. S. Green spot of passion fruit, a possible viral disease associated with infestation by the mite Brevipalpus phoenicis. Fitopatologia Brasileira, Campo Grande, v.22, p.555-559. 1997.

11. Kondo, H.; Maeda, T.; Shirako, Y.; Tamada, T. Orchid fleck virus is a rhabdovirus with an unusual bipartite genome. Journal of General Virology, Reading, v.87, p.2413-2421, 2006.

12. Locali, E. C. Sequenciamento de regiões genômicas do vírus da leprose dos citros. 2002. 87p. Dissertação (Mestrado) - Instituto de Biociências de Botucatu, Universidade Estadual Paulista, Botucatu.
13. Locali, E.C.; Freitas-Astua, J.; Souza, A.A.; Takita, M.A.; AstuaMonge, G.; Antonioli, R.; Kitajima, E.W.; Machado, M.A. Development of a molecular tool for the diagnosis of leprosis, a major threat to citrus production in the Americas. Plant Disease, Minnesota, v.87, p.1317-1321, 2003.

14. Lorenzi, H.; Souza, H. M. Plantas ornamentais no Brasil: arbustivas, herbáceas e trepadeiras. São Paulo. Plantarum, 1995, $720 \mathrm{p}$.

15. Lovisolo, O.; Colariccio, A.; Chagas, C. M.; Rossetti, V; Kitajima, E. W.; Harakava, R. Partial characterization of Citrus leprosis virus. In: Conference of the International Organization of Citrus Virologists, 13., 1996, Fuzhou. Proceedings. Riverside: INTERNATIONAL ORGANIZATION OF CITRUS VIROLOGISTS, 1996. p. $179-188$.

16. Lovisolo, O.; Colariccio, A.; Masenga, V. New experimental host further information on Citrus Leprosis Virus. In: Conference of the International Organization of Citrus Virologists, 14., Campinas, 2000. Proceedings. Riverside: INTERNATIONAL ORGANIZATION OF CITRUS VIROLOGISTS, 2000. p.164-173.

17. Maeda, T.; Kondo, H.; Misuhata, K.; Tamada, T. Evidence that Orchid fleck virus is efficiently transmitted in a persistent manner by the mite Brevipalpus californicus. In: International Congress of Plant Pathology, 7., 1998, Edinburgh. Disponível em: http:// www.bspp.org.uk/icpp98/1.13/18.html. Acesso em 23/fev./2003.

18. Musumecci, M. R.; Rossetti, V. Transmissão de sintomas de leprose dos citros pelo ácaro Brevipalpus phoenicis. Ciência e Cultura, São Paulo, v.15, p.228, 1963.

19. Rodrigues, J. C. V.; Kitajima, E. W.; Childers, C. C.; Chagas, C. M.; Machado, M. A. Citrus leprosis virus vectored by Brevipalpus phoenicis (Acari: Tenuipalpidae) on citrus in Brazil. Experimental and Applied Acarology, Amsterdam, v.30, p.161-197, 2003.

20. Ross, A.F. Identification of plant viruses. In: Corbett, M.K.; Sisler, H.D. (Ed.). Plant virology. Gainesville: University of Florida Press, 1964. p.68-92.

21. Rozen, S.; Skaletsky, H.J. Primer on the WWW for general users and for biologist programers. In: Krawetz, S.; Misener, S. (Ed.). Bioinformatics methods and protocols: methods in molecular biology. Totowa, Human Press, 2000. p.365-386

22. Salva, R. A.; Massari, C. A. Situação do ácaro da leprose no estado de São Paulo - Levantamento Fundecitrus, agosto 1995. In: Oliveira, C.A.I.; Donadio, L.C. (Ed.). Leprose dos citros. Jaboticabal: FUNEP, 1995. p. 13-16.

23. Sambrook, J.; Fritsch, E.F.; Maniatis, T. Molecular cloning: a laboratory manual. 2. ed. New York: Cold Spring Harbor Lab, 1989. 1659p. 